\title{
AGAINST THE "ART OF FORGETTING": MEMORY - MUSEUM - HISTORY'
}

MARLIES RAFFLER

\section{ABSTRACT/ABSTRAKT:}

The aim of the article is to extend the joint contribution of historical sciences and museums to the culture of memory by approaches of historical museology. Keeping in mind the tight connection between "remembering" and "keeping" (in terms of retention and disclosure of world knowledge), the presence of museality in its historical dimension is exemplified by selected museum collections from the ancient Orient to recent musealisation processes, in which the memoria is manifested in its physical form. With the help of historical and literary evidence and through the medium of approaches used in neuroscience (after Wolf Singer), the article demonstrates on the basis of a polarisation between ars oblivionalis (the art of forgetting) and ars memoriae (the art of memory) that the topic of mnemonics or, in other words, the art of memory keeping, is still present. The learning and remembering strategies which are based on placing objects and terms in familiar locations (loci) and creating imaginary associations (imagines agentes), are already known from the Antiquity. Through the medium of models of the Renaissance art of memory they were incorporated in the concept of museum collections and made them the places of memory, preservation and knowledge. Theoretical base of the methods intended to order the knowledge is contained in early treatises by Quiccheberg, Hainhofer, Major and Neickelius. The problem area comprises a wide
https://doi.org/10.5817/MuB2017-2-1 spectrum of topics beginning with musealisation as a term for a sort of conservation and therewith also compensation of items whose existence is threatened by an altered attitude to history, through to modern methods of a participative or "activist" museum which gave rise to new types of "memory making" and "memory keeping".

\section{Proti „umění zapomínat“:} pamět - muzeum - historie

Cílem článku je rozšířit společný přínos historické vědy a muzeí ke kultuře paměti o poznatky z oblasti historické muzeologie. Př́ítomnost muzeality v jejím historickém rozměru je s vědomím těsného propojení mezi „zapamatováním“ a „uchováním“ (ve smyslu uchování a předávání světových znalostí) názorně prezentována na příkladech konkrétních muzejních sbírek od starověkého Východu až po recentní procesy muzealizace, v kterých je memoria reálně vyjádřena ve fyzické podobě. S pomocí historických a písemných dokladů a také prostřednictvím metod z oblasti neurovědy (podle Wolfa Singera) článek na základě polarizace mezi ars oblivionalis (umění zapomínat) a ars memoriae (umění paměti) upozorňuje na skutečnost, že téma mnemotechniky nebo také umění zapamatování je i v dnešní době stále aktuální. Strategie učení a pamatování, které jsou založeny na umístění informací a pojmů do geograficky známého prostředí (loci) a vytváření pamětových obrazů (imagines agentes), jsou známy již od antiky. Prostřednictvím pamětových modelů byly v období renesance zakomponovány i do muzejních sbírek a přetvořily je $\mathrm{v}$ místa paměti, uchování a vědění. Teoretické základy metod určených k uspořádání vědomostí najdeme v starších muzeologických traktátech autorů Quiccheberga, Hainhofera, Majora a Neickelia. Zmíněná problematika zahrnuje širokou škálu témat počínaje muzealizací jako označením určitého druhu konzervace a tím i kompenzace toho, čemu $\mathrm{v}$ důsledku změněného postoje k historii hrozí zničení, až po moderní metody participativního a „aktivistického“ muzea, které dává zrod novým typům vytváření a uchování paměti.

\section{KEYWORDS/KLÍČOVÁ SLOVA:}

history - historical museology museality - musealisation process remembrance - individual and collective memory - authenticity theatrum mundi - museological treatises

historie - historická muzeologie muzealita - proces muzealizace pamatování - individuální a kolektivní pamět - autenticita theatrum mundi - muzeologické traktáty

1 Transcript of a lecture given in the workshop and "Open Round Table of Museology" at the Masaryk University in Brno on October 17-21, 2016 in Brno. 
"Without memory and objectification, which springs from memory itself because memory needs objectification for its own remembrance, all the acts of life, spoken word and thoughts would vanish without a trace."

"Museums are in the business of history" - "Museums are in the memory business"4

One of the central topics of Historical Museology is the question of how museality - as an existing moral and value concept in the mentality of certain cultures is materialized by individuals or collectives and how it can be detected and demonstrated. In so doing, we use a repertoire, which was developed in the Historism (especially by Johann Gustav Droysen $)^{5}$ predominantly for the written sources - criticism of sources: firstly heuristic, then source analysis of external and internal characteristics and thirdly hermeneutics/interpretation of each source relating on its own era. Only a combination of different methods and different types of sources allows statements about the past or a concrete phenomenon.

Museology has been struggling to prove its methodological autonomy. So in the following article Historical Museology is trying to point out its view of how methods of Theoretical museology have to be combined with historical science and how they have to interact in order to gain insight into "authentic" evidence of the past, on the example of the "art of memory" (ordo - locus - memoria) and the

\footnotetext{
2 ARENDT, Hannah. Vita activa oder Vom tätigen Leben. München, 1981, p. 87 sq.

3 According to the formulation by KNELL, Simon J. (ed.). Museums and the Future of Collecting. Aldershot: Ashgate, 2004.

4 "Museums see themselves in the business of creating historical and cultural memory." MCLAUGHLIN, Hooley. The Pursuit of Memory: Museums and the Denial of Fulfilling Sensory Experience. Journal of Museums Education, 1998 , Experience. Journal of

phenomenon of preserving memory in museal collections from ancient to recent times.

The common goal of history as a scientific discipline and the museum as an institution is, as F. Waidacher and others have already postulated, to maintain the existential human need for remembrance and derive from it the definition and orientation tools for the present and the future $^{6}$ - being aware of the fact that there is a permanent process of reinterpretation and new explanation. Their function as an "official custodian" was assigned to them by the society, and both history and museum serve as a memory bank (storage of memories) and a data-warehouse (place of information and documentation) to the general public. ${ }^{7}$ Moreover, the same research methods (e. g. applying hermeneutic source criticism also to museum analysis ${ }^{8}$ ) and differences in methods and presentation forms are used to derive and offer definition and orientation tools for the heterogeneous society of today and tomorrow. Both of them establish standards with their unbiased timeless statements on historical processes and/or on the nature of things regarding the history of art, culture and

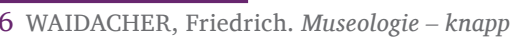
gefasst. Mit einem Beitrag von Marlies Raffler. Wien: UTB, 2005, p. 15. "Museums see themselves in the business of creating historical and cultural memory." MCLAUGHLIN, Hooley. The Pursuit of Memory: Museums and the Denial of Fulfilling Sensory Experience. Journal of Museums Education, 1998, vol. 23, no. 3, p. 11

7 Sometimes even as an information self-service store, where information from the past is taken out but only pieces of this information are then displayed in an unfiltered and non-reflected way.

8 Cf. THIEMEYER, Thomas.

Geschichtswissenschaft. Das Museum als Quelle. In BAUR, Joachim (ed.). Museumsanalyse. Methoden und Konturen eines neuen Forschungsfeldes. 2nd ed. Bielefeld: Transcript, 2013, pp. 73-94.
}

nature. ${ }^{9}$ Another common feature of historical science and museums is the demand for objectiveness or objective reconstruction and authenticity of texts and objects. Despite - mainly financial dependencies, both of them must claim independency towards (dayto-day) political or even ideological influence. But both the history of historiography and the genesis of museums experience conflicts of ideas and institutions against the backdrop of the contemporary perception of history, and reflect historical, national or nationalistic, biologistic as well as methodical and scientific theoretical approaches. "More than that, history and museums take the idea of a memory place and combine it with a more powerful device: storytelling and the construction of a narrative."10

The memory of society needs myths, pictures, rituals, to which it can relate its remembrance. We historians deconstruct and disenchant these myths as constructions of contemporary "Zeitgeist". Historical science analyses the past which defies an experimental approach due to its non-repeatability; this uniqueness and non-repeatability "is no privilege of this discipline, but always one of the epistemic problems, which also the exact natural sciences have to cope with." 11 Among the issues addressed in this article is the question, whether the achievements

\footnotetext{
9 "The standards of a society and its scientific self-reflection can be recognised through the selfimposed task of museums to select objects from the richness of reality, to preserve, explore and present them." RAFFLER, Marlies. Museum - Spiegel der Nation. Zugänge zur Historischen Museologie am Beispiel der Genese von Landes- und Nationalmuseen in der Habsburgermonarchie. Wien, Köln, Weimar: Böhlau, 2007, p. 79.

10 MCLAUGHLIN, Hooley. The Pursuit of Memory: Museums and the Denial of Fulfilling Sensory Experience. Journal of Museums Education, 1998, vol. 23, no. 3, p. 11

11 SINGER, Wolf. Wahrnehmen, Erinnern, Vergessen. Über Nutzen und Vorteil der Hirnforschung für die Geschichtswissenschaft. Eröffnungsvortrag des 43. Deutschen Historikertages am 26.09.2000 in Aachen [online]. [cit. 2017-1122]. Available from www: <http://www.brain. mpg.de/fileadmin/user_upload/images/Research/ Emeriti/Singer/Historikertag.pdf $>$.
} 
of neurology play any role in this regard and whether they become part of the "history" and "museum" game, while the research findings on the topics concerned transform the ability to focus, guide and lead our attention into displaying, interpretation, exhibitions and presentations.

\section{The art of memory}

A seemingly banal finding has wide-reaching consequences for the interaction between history and museums and the museum collecting itself. "Past experience is not the same as it was when it took place. It can be forgotten or remembered again. But for this purpose it must be stored."12

One of the world's most famous neuroscientists, Wolf Singer, says that memory is connected with an updating of the perspective from which the remembered contents are perceived.

In order to show that the polarisation of ars oblivionalis (the art of forgetting) against ars memoriae (the art of memory), which already arose and consolidated between Friedrich Nietzsche and Jacob Burckhardt, ${ }^{13}$ is also present in nowadays discourse, we will first demonstrate on literary works and their fundamental ideas that the topics of mnemonic or the art of forgetting are still living and ever-present. The book by Joshua Foer "Moonwalking with Einstein"14 is dealing with possible capacities but also limits of the human brain and exemplifies by a "one man's memory odyssey" how a (partial) memory loss can

12 BABEROWSKI, Jörg. Der Sinn der Geschichte. Geschichtstheorien von Hegel bis Foucault. 3rd ed.

München: C. H. Beck, 2014, Chapter 8: Erinnerung und Kollektives Gedächtnis, p. 161.

13 See WEINRICH, Harald. Gibt es eine Kunst des Vergessens? Basel: Schwabe, 1996.

14 FOER, Joshua. Moonwalking with Einstein: the art and science of remembering everything. London: Penguin Books, 2012. occur. The protagonist of the book is searching for answers and meets scientists, patients with amnesia, world champions in the art of memory, etc. The latter explain that they achieve their so-called "super-brain" performance not by any extraordinary intellectual power, but by applying a specific learning strategy, which is based on topographic localisation of images and terms. ${ }^{15}$ This approach applies the method of loci in connection with imagines, which are already known from the 16th century theatrum mundi by Giulio Camillo Delminio, and subordinates it to the principle of "interlinking everything". ${ }^{16}$ Ordo as arrangement and loci as places to remember are related to imagines agentes ("active images", allegoric image systems) which are central terms of mnemonics, the art of memory. A representative of the art of memory in the Renaissance period based his version of the theatrum mundi as a mnemonic aid on the exceptional ability to remember, which Simonides of Keos was said to have according Ciceros " $D e$ oratore": Giulio Camillo Delminio with his treatise "L'idea del Theatro", published (posthumously) in 1550.

\section{A representative of the art of} memory in the Renaissance period based his version of the theatrum mundi as a mnemonic aid on the exceptional ability to remember, which Simonides of Keos was said to have according Ciceros "De oratore": Giulio Camillo Delminio

\footnotetext{
15 In this context, Jan Assmann remarks succinctly that memory needs places and tends to spatialization. Cited after BABEROWSKI, Jörg. Der Sinn der Geschichte. Geschichtstheorien von Hegel bis Foucault. 3rd ed. München: C. H. Beck, 2014, Chapter 8: Erinnerung und Kollektives Gedächtnis, p. 170.

16 RAFFLER, Marlies. Museum - Spiegel der Nation. Zugänge zur Historischen Museologie am

Beispiel der Genese von Landes- und Nationalmuseen in der Habsburgermonarchie. Wien, Köln, Weimar: Böhlau, 2007, p. 90; YATES, Francis. Gedächtnis der Renaissance: das Gedächtnistheater des Giulio Camillo. In YATES, Francis. Gedächtnis und Erinnern. Mnemonik von Aristoteles bis Shakespeare. 5th ed. Berlin: Akademie, 1999, pp. 123-161.
}

with his treatise "L'idea del Theatro", published (posthumously) in 1550. Sketches show that the construction reminds in its form of Shakespeare's Globe Theatre, but it remains unclear whether the wooden model, which was built for Francis I of France, also existed as a walk-through building of a theatre of memory. The idea of theatre as a place of overview can be traced back to Apuleius, but the principle of theatre by Giulio Camillo is reverse - the orator or observer stands in the orchestra, and seven seat rows bear the image of the universe in a hierarchical arrangement with the aim to "keep the eternal contents of all things forever". ${ }^{17}$ Camillo's intricate system, which is hard to see through, goes far beyond the scope of a purely mnemonic model, into the realm of "hermetic sciences". ${ }^{18}$ A reception in literature can be found in the novel "Terra Nostra" by Carlos Fuentes. ${ }^{19}$

This model is also addressed in a lecture by W. Singer. ${ }^{20}$ Here he does not deal with material remains but, as it is known from the historical source criticism, with sources of "tradition", which are already themselves a result of human perception, memory

\footnotetext{
17 In his publication "Meaning in the visual arts", Erwin Panofsky has proven that Titian's Allegory of Prudence consciously portrays a wolf, a lion and a dog, through which prudentia looks into the past, present and future.

18 Hermetism has been defined as an esoteric tradition based primarily on writings attributed to Hermes Trismegistos. In the Early Modern Period it was often used as a synonym for alchemy and occultism. Corpus Hermeticum was rediscovered in the Renaissance. The owner of the manuscript, Cosimo Medici, entrusted the humanist Marsilio Ficino with Latin translation of the writing. Its impact can be traced to as late as the 17th century.

19 FUENTES, Carlos. Terra Nostra. Barcelona: Martin Secker \& Warburg Ltd, 1977. Further information in: NEUMEISTER, Sebastian. Der Schriftsteller und die Erinnerung: Carlos Fuentes und das "Teatro della memoria" des Giulio Camillo Delminio. Ibero-amerikanisches Archiv, 1990, vol. 16 , no. 1 , pp. $31-47$

20 SINGER, Wolf. Wahrnehmen, Erinnern, Vergessen. Über Nutzen und Vorteil der Hirnforschung für die Geschichtswissenschaft. Eröffnungsvortrag des 43. Deutschen Historikertages am 26.09.2000 in Aachen [online]. [cit. 2017-11-22]. Available from www: <http://www brain. mpg.de/fileadmin/user_upload/images/Research/ Emeriti/Singer/Historikertag.pdf $>$.
} 
and interpretation, protocols of participants, reports "which refer to assumed realities", and explains the evolution of human episodic memory. Singer believes that this has originally been a memory for places and their relations to each other. Here also we can find roots of the above-mentioned legend of Simonides of Keos, who just imagined where individual participants in the ominous banquet were sitting before they were killed by collapsing walls, in order to remember their names. The basic principle of mnemonic methods is to imagine first the places and spatial relations and then associate them with contents to remember. "How much indeed the alleged reality of remembered facts and circumstances is based on the reconstruction of relations between fragmentary and separated memory traces, can be inferred from frequently occurring mistakes", Singer says. ${ }^{21}$ This has widereaching consequences for the assessment of authenticity of memories, because to remember also means to inscribe again, and it is likely that "during this new consolidation process, the context in which the remembrance took place is also co-written and added to the original memory. So it is well possible that the old memory is embedded in a new context and therewith actively modified. If this would be the case, then the remembrance would always go hand in hand with an updating of the perspective from which the remembered contents are perceived. The original perspective would be reshaped and modified through the medium of all the other experiences, which the observer has acquired since his/her first encounter with the remembered content. The original piece of memory, being told and

\footnotetext{
21 SINGER, Wolf. Wahrnehmen, Erinnern, Vergessen. Über Nutzen und Vorteil der Hirnforschung für die Geschichtswissenschaft. Eröffnungsvortrag des 43. Deutschen Historikertages am 26.09.2000 in Aachen [online]. [cit. 2017-11-22]. Available from www: <http://www brain. mpg.de/fileadmin/user upload/images/Research/ Emeriti/Singer/Historikertag.pdf $>$.
}

retold, thus might be continuously modified and adapted to current opinions of the narrator." 22

The topics of remembrance and collective memory as well as the problematic contradiction between memory and historical science are addressed by Jörg Baberowski in his work Sinn der Geschichte. ${ }^{23}$ A variation of the motto "Quod non est in actis non est in mundo" might sound: "What is not remembered, does not exist" - we can refer to a memory when we remember it and communicate about it with others. However, remembrance is neither "recalling" nor "storing". ${ }^{24}$ When we pay attention first to individual memory: since it is always a reinterpretation (according to Freud), that is, no retrieval or recognising of objects, but a new understanding of what was once already understood in a way, the same past is remembered and interpreted again and again in a new way. Remembrance is an associative activity, which is searching for meaning and generates meaning. We can read and interpret traces, when we remember them and communicate with the others about how to read them. Baberowski cites in this regard Paul Valéry's concept of memory as a construction, not accumulation. ${ }^{25} \mathrm{He}$ also refers to Émile Durkheim, who emphasized

\footnotetext{
22 SINGER, Wolf. Wahrnehmen, Erinnern, Vergessen. Über Nutzen und Vorteil der Vergessen. Uber Nutzen und Vorteil der
Hirnforschung für die Geschichtswissenschaft. Eröffnungsvortrag des 43. Deutschen Historikertages am 26.09.2000 in Aachen [online]. [cit. 2017-11-22]. Available from www: <http://www.brain. mpg.de/fileadmin/user_upload/images/Research/ Emeriti/Singer/Historikertag.pdf $>$.

23 Cf. BABEROWSKI, Jörg. Der Sinn der Geschichte. Geschichtstheorien von Hegel bis Foucault. 3rd ed. München: C. H. Beck, 2014, Chapter 8: Erinnerung und Kollektives Gedächtnis, p. 159-173.

24 BABEROWSKI, Jörg. Der Sinn der Geschichte. Geschichtstheorien von Hegel bis Foucault. 3rd ed. München: C. H. Beck, 2014, Chapter 8: Erinnerung und Kollektives Gedächtnis, p. 159.

25 "Wir lesen und deuten also Spuren, wenn wir uns erinnern und verständigen uns mit anderen darüber, wie sie zu lesen sind." BABEROWSKI, Jörg. Der Sinn der Geschichte. Geschichtstheorien von Hegel bis Foucault. 3rd ed. München: C. H. Beck, 2014, Chapter 8: Erinnerung und Kollektives Gedächtnis, p. 162.
}

the community-building function of remembrance and memory. ${ }^{26}$ All the factors, which we take into account when we cope with the methodical problem of spatial fixedness of a historian, also apply to memory. Despite our individuality we are rooted in traditions, language, time, etc. What we call memory cannot be separated from collective ideas which dominate a society. This discovery was made by a disciple of Henri Bergson and Émile Durkheim, Maurice Halbwachs who presented it in his work "On collective memory" (Les cadres sociaux de la mémoire), which is dealing with social background of memory. ${ }^{27}$ His ideas significantly influenced Marc Bloch and Jacques Le Goff. While Bergson still associated remembrance with individual experiences of duration (durée), Halbwachs already accentuated the collective character of remembrance. The existing ideas, which are shared by people, represent the structuring agent of individual memory. Culture in which we live forms our memory this fund is "collective memory". 28 The memoria reaches into the fundamental area of thinking and acting of both individuals and collectives. The abundant givenness in religion, interpretation of the world and knowledge shall through the medium of memory and remembrance work against oblivion and death. Through memory we shall overcome our own lifeworld, lifetime and lifespace and derive from them new orientation, sensemaking and

\footnotetext{
26 BABEROWSKI, Jörg. Der Sinn der Geschichte. Geschichtstheorien von Hegel bis Foucault. 3rd ed. München: C. H. Beck, 2014, Chapter 8: Erinnerung und Kollektives Gedächtnis, p. 159.

27 M. Halbwachs has further developed the theory of social conditionality of individual memory; he extended the term mémoire collective to the area of cultural transmission and formation of tradition.

28 Cf. BABEROWSKI, Jörg. Der Sinn der Geschichte. Geschichtstheorien von Hegel bis Foucault. 3rd ed. München: C. H. Beck, 2014, Chapter 8: Erinnerung und Kollektives Gedächtnis, p. 166.
} 
search for identity. Particularly the research approaches tending to "postmodernism" are vividly interested in "storehouses of knowledge", "places of knowledge" (after A. Ophir and St. Shapin) or rather "places of research", "storehouses of memory". ${ }^{29}$ Encyclopaedias, libraries and museums, which are referred to as "treasuries of world knowledge", 30 come into focus of knowledge search. Topical research approaches in the realm of memory culture (keyword: Pierre Nora: "lieux de mémoire" - places of memory) define the term "cultural memory", which was introduced by the sociologist Maurice Halbwachs (1924 "Les cadres sociaux de la mémoire) and the mentality historian Jacques Le Goff, as the "knowledge, on which the unity and particularity of a society is based". ${ }^{31}$ In this concept, the object of this knowledge is the past in the form of the legitimising and substantiating prehistory of today. This perception of unity and particularity, which is based on selected events in the past, is called historical awareness in terms of an insight into the becomingness of the present condition.

29 of fundamental importance in this regard are the works within the scope of the Commission for Cultural Studies and History of Theatre at the Austrian Academy of Sciences. Cf. CSÁKY, Moritz and Peter STACHEL (eds.). Speicher des Gedächtnisses. Bibliotheken, Museen und Archive. Volume 1: Absage an und Wiederherstellung von Vergangenheit. Kompensation von Geschichtsverlust (Wien: Passagen Verlag, 2000) and Volume 2: Die Erfindung des Ursprungs. Die Systematisierung der Zeit (Wien: Passagen Verlag, 2001).

30 For essential reading on this topic, see ERNST, Ulrich. Memoria und ars memorativa in der Tradition der Enzyklopädie. Von Plinius zur Encyclopédie française. In BERNS, Jörg Jochen and Wolfgang NEUBER (eds.). Seelenmaschinen. Gattungstraditionen, Funktionen und

Leistungsgrenzen der Mnemotechniken vom späten Mittelalter bis zum Beginn der Moderne. Wien, Köln, Weimar: Böhlau, 2000, pp. 109-168.

31 According to the definition by Jan and Aleida Assmann, who strongly influenced the 20th century theoretical and methodical discourse with their publications. Cf. ASSMANN, Aleida. Erinnerungsräume. Formen und Wandlungen des
kulturellen Gedächtnisses. München: C. H. Beck, 1999; ASSMANN, Jan. Kollektives Gedächtnis und kulturelle Identität. In ASSMANN, Jan and Tonio HÖLSCHER (eds.). Kultur und Gedächtnis. Frankfurt a. M.: Suhrkamp, 1988, pp. 9-19.

\section{On the role of historical museology}

Here the historiography has an important function as an auxiliary science of museology. It creates a frame for connotations and for setting the objects into the context of origin and meanings. An interlink is offered by historical museology. It is a subsystem or a partial discipline of general museology. It is eclectic both in methods and in theory - i.e. it uses the methods and theories of other scientific disciplines and develops on their basis its own methods and theories. The purpose of historical museology is to study, describe and analyse chronological and spatial context, in which museality occurs and is reflected. Within this process it regards the subject both from the perspective of its historical development and in relation to the present. ${ }^{32}$ The cognitive work of historical museology encompasses two partial fields: firstly, the history of museology as a theoretical construct and, secondly, the emergence of museality in its historical dimension and study of the history of musealisation. Going the way from curiositas over memoria to systematic dissemination of knowledge can help a historical museologist not only to understand the museum as an institution, but also to tap new (and old) forms of knowledge acquisition. ${ }^{33}$

\section{All the world is a stage for memory}

Being aware of the tight connection between "remembrance" and "retention", it will be exemplified with the help of selected museum collections how the protection,

\footnotetext{
32 WAIDACHER, Friedrich. Handbuch der Allgemeinen Museologie. 2nd ed. Wien, Köln, Weimar: Böhlau, 1999, p. 65.

33 Cf. KORFF, Gottfried. Das historische Museum. Labor, Schaubühne, Identitätsfabrik. Frankfurt a. M.: Campus-Verlag, 1990.
}

keeping and disclosure of world knowledge can be implemented: as examples we will adduce the excavation reports by Leonard C. Wooley from Ur, we will elucidate the role of ars memoria in the knowledge model by Giulio Camillo and analyse the displays of cabinets of curiosities and wonders as well as early theoretical writings and museological treatises, which are represented here by the pertinent works by Samuel Quicche(l)berg, Philipp Hainhofer, Johann Daniel Major (and his "Epigon" Neickelius). ${ }^{34}$ When we take a look (in chronological sequence of the genesis of museum collections) at the Ancient Orient and the Classical Antiquity, together with $\mathrm{H}$. Aigner ${ }^{35}$ we must first bring into question the standard introductory sentence from many publications on the history of collecting (e. g. by K. Pomian), claiming that our museums owe their name to ancient Temples of the Muses. The Museion in Alexandria, whose library attracted many prominent scholars, surely may have been eponymic in this regard, but there is no evidence that the Muses were worshipped in temples. A sort of parallel between the temples of Greeks and Romans and our present-day museums can most likely be seen in the realm of offerings, whose main purpose was memoria - to recall things by the people and by the gods. The metaphor of Noah's Ark as the first "collection", which is based both on the pursuit of completeness and on retention - "collection as

34 The analysis of "Museographia. Oder Anleitung zum rechten Begriff und nützlicher Anlegung der Museorum oder Raritäten. Kammern..." (1727) is the topic of a next study.

35 AIGNER, Heribert. Museale Vorläufer vom Alten Orient bis in die griechisch-römische Welt. Curiositas, 2001, no. 1, pp. 81-87. 
salvation", ${ }^{36}$ also can provide an insight in this sense. ${ }^{37}$

As a predecessor in the Ancient Orient can be named Shutruk Nahhunte, the King of Elam, who kept the trophies from his victory over Babylon in a temple museum. ${ }^{38}$ These spoils of war include the famous items "Code of Hammurabi" and the "Victory Stele of Naram-Sin" (3rd millennium BC) which - equipped with a new inscription - carries on the glory of the victorious ruler and thereby acts consciously as a bearer of double memory. Nebuchadnezzar II of Babylon with his palace museum comes already nearer to tasks and demands which are placed on present-day museums. He established in his palace a collection of inscriptions, reliefs, steles, statues etc. from the past "to astonish the folks"; old inscriptions were deciphered, old buildings were reconstructed and excavations were carried out. Even though the objects were partly spoils of war, a well-thought selection was made to demonstrate diversity, things worth remembering, and a long period of time. Like the other temples of the Akkadian Period (Sippar, Babylon, Nippur), the Sin Temple in Ur also contained collections of historically significant monuments and documents. Important is that the excavations in the Palace of BelShalti-Nannar, daughter of the last king of the Chaldeans (6th cent. $\mathrm{BC}$ ), yielded besides shrines, commercial rooms and "training school texts" also indications of a little museum of local antiquities in connection with the school,

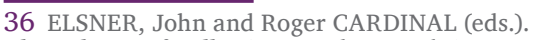
The Cultures of Collecting. London: Reaktion Books, 1996, p. 1.

37 AIGNER, Heribert. Museale Vorläufer vom Alten Orient bis in die griechisch-römische Welt. Curiositas, 2001, no. 1, p. 82.

38 Examples from GALTER, Hannes D.

Geschichte als Bauwerk. Der Aššurtempel und das assyrische Geschichtsbewusstsein. In FRAME, G. (ed). From the Upper to the Lower Sea. Festschrift für A. K. Grayson. Leiden, 2004. [non-paginated manuscript of the author]. which was probably administered by the above-mentioned priestess. Objects from more than thousand years, statues, a clay nail of a king, a votive mace-head, etc. were found accumulated within a small area. There was a clay cylinder inscribed with four columns of something like a list of collectibles containing the data on their origin or donation. ${ }^{39}$

In the early modern era, places of knowledge were represented by special collection rooms, which were recommended, for example by J. A. Comenius, as a refuge for scholars and were referred to as "studiolo" in the Renaissance period. As examples we can name the facilities of Federigo Montefeltre and his successor Guidobaldo in the Ducal Palace of Urbino, as well as special rooms established by the collector Paolo Guinigi in his palace in Lucca (before 1530). Such a room was regarded as the most intimate place, bedchamber, study room and private collection of a humanistic scholar. It often was very narrow, spartanly furnished and dimly lit. In the case of Urbino, it was raised by sculptures of the greatest minds of Antiquity in the broadest sense and of the present times to a "pandemonium" of human knowledge and skills. ${ }^{40}$

An independent type, mainly dominant in Mannerism, was the cabinet of curiosities and wonders, a representation of theatrum mundi. The period which F. Waidacher referred to as a "palaeomuseum epoch" was a time of the first "museum treatises", that is, the first theoretical disputes about "perception, identification, sorting and interpretation" of

\footnotetext{
39 WOOLEY, C. Leonard. The Excavations at Ur, 1924-1925. The Antiquaries Journal, 1925, vol. 5, no. 4, p. 384.

40 SÜNDERHAUF, Esther. Im Labyrinth des Visus. Wahrnehmungsformen in der Kunstkammer am Beispiel von Studiolo und Tribuna des Francesco I. de Medici. Frühneuzeit-Info, 1996, vol. 7, no. 2, pp. 215-233.
}

objects and their mnemonic significance. Since the 16th century, the metaphoric concept of theatrum, theatrum mundi, theatrum humanae vitae, theatrum sapientiae, theatrum naturae personified an encyclopaedic reappraisal of knowledge in terms of disposition, an arrangement only constructed for the collection. The topic of theatrum mundi as a title of encyclopaedic works was implemented in humanistic literature.

As an excellent example of the early museum theory we can name the work by the Belgian physician Samuel Quiccheberg "Inscriptiones vel tituli theatri amplissimi...", published in 1565 in Munich, which is available in a commented translation by Harriet Roth. ${ }^{41}$ The trend-setting treatise by Quiccheberg is treated here for the first time in its entirety, which enables to embed it into a biographic and scientific historical context. The translation is supplemented with introductory biographic remarks on Quiccheberg, a detailed overview of the writings and collections which he had at his disposal with special emphasis on the model role of "L'Idea del Theatro" by Giulio Camillo, an explanation of its concept of museums, and an extensive commentary on the "organisation and method of Quiccheberg's museum theory". ${ }^{42}$ Quiccheberg bases himself on G. Camillo, who - approximately at the same time as Salomon Gesner and in competition with his ordering principle - clings to the antique system of Mnemesis and, in search for a system of metaphysical

\footnotetext{
41 ROTH, Harriet (ed.). Der Anfang der Museumslehre in Deutschland: das Traktat "Inscriptiones vel tituli theatri amplissimi“" von Samuel Quiccheberg; lateinisch-deutsch. Berlin: De Gruyter, 2000.

42 KELLER, Barbara. Mnemonik als kreatives Verfahren im 16. und 17. Jahrhundert. In ASSMANN, Aleida and Dietrich HARTH (eds.) Mnemosyne. Formen und Funktion kultureller Erinnerung. Frankfurt a. M.: Fischer-Taschenbuch-Verlag, 1991, pp. 200-216.
} 
places to remember, develops an auxiliary mnemonic model in the form of a theatrical construction. ${ }^{43}$

The metaphoric concept of theatrum, theatrum mundi, theatrum naturae, theatrum sapientiae, orbis theatrum personified approximately since the 16th century an encyclopaedic reappraisal of knowledge in terms of disposition, an arrangement constructed specifically for a "collection". ${ }^{44}$ The medieval word speculum was gradually replaced by theatrum derived from théa (= to watch). The search for a "proper" view of the world and of oneself, a doubt about the validity of perception induced by the perspectival distortion of the mirror, became the central topic in the Renaissance theory of art. ${ }^{45}$ The efforts to form something mimetically (not the imitatio) and to collect something are phenomena, which since the 15th century can be encountered in various collections striving to capture and retain things, and it is surely no coincidence that they occur parallel to each other in the course of historical development. Both of them anticipate a very special relationship to the world of things, which manifests itself in the conscious perception. E. Sünderhauf sets up a theory, according to which the form of collecting practised in the cabinets of curiosities was connected with new perspectives. ${ }^{46}$ And these are defined as: simultaneous watching, perceptive watching

43 YATES, Francis. Gedächtnis der Renaissance: das Gedächtnistheater des Giulio Camillo.

In YATES, Francis. Gedächtnis und Erinnern.

Mnemonik von Aristoteles bis Shakespeare. 5th ed. Berlin: Akademie, 1999, pp. 123-161.

44 See also OLMI, Guiseppe. Dal "Teatro del mondo" ai mondi inventariati: aspetti e forme del collezionismo nell' età moderna. In OLMI, Guiseppe. L'inventario del mondo. Catalogazione della natura e luoghi del sapere nella prima età moderna. Bologna: Il Mulino, 1992, pp. 165-209.

45 Further on this topic: KLEINSPEHN, Thomas. Der flüchtige Blick. Sehen und Identität in der Kultur der Neuzeit. Reinbek bei Hamburg: Rowohlt-

Taschenbuch, 1991, 59 sq.

46 Cf. this passage: RAFFLER, Marlies. Sammeln, die ordnende Weltsicht. Aspekte zur Historischen Museologie. Curiositas, 2001, no. 1, pp. 67-80. and employment of the central perspective $^{47}$ and, in addition to Sünderhauf, we could also name the reflection. The perspectival distortion, however, is in a deep contradiction to proper perception of reality. ${ }^{48}$ The "view" is a guide in the process of selection of objects. Even though the wall panels of the Palazzo in Urbino already created an illusion of space, the space in the 15th century, before Camillo's achievement, "was not yet organised as a walk-through model of the world". ${ }^{49}$ Between the theatrum mundi and the collection catalogue of later organised and gradually more and more specialised collections, there is "a new way of merging things together with speech and view"; ${ }^{50}$ the presentation forms are changing. Under the influence of new "professional literature" with instructions for establishment of museums and for classification and systemization, the old cabinets of curiosities and wonders laying focus on peculiarity and formidability were gradually transformed into collections of a new type. The rooms became dependent on the focus of the respective collection. Natural history cabinets, herbaria, botanic gardens and zoological collections are established, where individual objects can be studied.

In connection with the general change of the knowledge-based society, which can be dated to the mid-16th century, and with special

\footnotetext{
47 SÜNDERHAUF, Esther. Im Labyrinth des Visus. Wahrnehmungsformen in der Kunstkammer am Beispiel von Studiolo und Tribuna des Francesco I. de Medici. Frühneuzeit-Info, 1996, vol. 7, no. 2, p. 220.

48 Cf. KLEINSPEHN, Thomas. Der flüchtige Blick. Sehen und Identität in der Kultur der Neuzeit. Reinbek bei Hamburg: Rowohlt-Taschenbuch, 1991, esp. 59.

49 BESSLER, Gabriele. Wunderkammern einst und heute - die Welt im Raum. Konzeptuelle Ansätze für museale Kunstkammer-

-Inszenierungen. In ULFERTS, Gert-Dieter and Thomas FÖHL (eds.). Von Berlin nach Weimar. Von der Kunstkammer zum Neuen Museum. München, Berlin: Deutscher Kunstverlag, 2003, p. 236.

50 FOUCAULT, Michel. Die Ordnung der Dinge. 2nd ed. Frankfurt a. M.: Suhrkamp Taschenbuch Wissenschaft, 1978, p. 172.
}

regard to collecting intentions, three authors and their writings gained in importance: Philipp Hainhofer with his "descriptions of curiosity cabinets" , ${ }^{51}$ Samuel Quiccheberg with his "Inscriptiones vel tituli theatri amplissimi..." and Johann Daniel Major with his treatise "Unvorgreiffliche Bedencken..... Their works follow the principles of "getting the picture" and "interlinking everything" and they should be contrasted mainly with regard to the new way of perception and the intermingling of the real space and the artificially created image spaces. These approaches supplement the above-mentioned auxiliary mnemonic constructions and memory systems and create a transition between the localisation in space, i.e. visually and spatially shaped memory (personified by Hainhofer), and the memory shaped by writing (represented by Quiccheberg and Major).

We spoke about loci, about places to remember, localisation in space and about the Mimesis - and here Hainhofer miniaturises his theatrum mundi. "The product of nature as a shining example, the artefact as an ennobling, soulful transformation of nature through human hands in three steps: ars naturam superat / ars naturam imitat / ars naturam adaequat." ${ }^{52}$

In the small space of curiosity cabinets, as construed by Hainhofer, the synthesis of philosophy, religion, natural sciences and art should be completed and the boundaries between natura and ars should be nullified. The same principle -

51 Cf. DOERING, Oscar. Des Augsburger Patriciers Philipp Hainhofer Reisen nach Innsbruck und Dresden. Wien: C. Graeser, 1901.

52 BACH, Gerlinde. Philipp Hainhofer und ein Kabinettschrank des Kunsthistorischen Museums in Wien. Philipp Hainhofer - Kunsthändler, Agent und Auftraggeber zahlreicher Kabinettschränke. In Jahrbuch der Kunsthistorischen Sammlungen in Wien, 1995/1996, vol. 91, p. 148. 
according to H. Roth - is used by Samuel Quiccheberg to elucidate the five classes of "inscriptiones signum Mercurio". Firstly, the historic department based on theological, planetary and numerical order, with a gallery of ancestors and vedutas; secondly, the artificialia, thirdly, the naturalia, fourthly - based on artes mechanicae - the artificialia and scientifica referring to instruments, tools, weapons and a doll collection interesting from a socio-historical and ethnological aspect. The fifth department encompasses the art gallery itself. Complementary section titled "Musea et Officina" includes Quiccheberg's treatises about the founding, selection and installation concept of a library, more precisely the Munich Royal Library, which should have extended the collection, as well as about archives and workshops. The central role was played by "Admonitio et Consilium", by which Quiccheberg wanted to ensure the "optimal use of the text". ${ }^{53}$ The treatise is accompanied by a listing of prevailingly German-speaking collectors who are presented by Roth in the form of extensive biographies. The top of this hierarchic system is occupied by secular and spiritual princes, men of letters and patrician collectors, the second rank belongs to collectors at court and the creators of "theatri sapientiae"; and finally, in the third place, follows - quasi as a mirror to the vivid collecting activity in the second half of the 16th century - a listing of mainly regional collectors, artists and artisans. Some influence on the 17th century collecting principles or even on the whole educational system (it is worth to consider the effect of Jan Amos Comenius/ Komenský's visit to England in 1641) was also exerted by the

\footnotetext{
53 ROTH, Harriet (ed.). Der Anfang der Museumslehre in Deutschland: das Traktat "Inscriptiones vel tituli theatri amplissimi“" von "Samuel Quiccheberg; lateinisch-deutsch. Berlin: De Gruyter, 2000, p. 259.
}

"museum-utopian" work by Francis Bacon, more precisely by the pages of "Nova Atlantis" (written before 1617 and published 1627) concerning the "Salomon's House", namely Chap. IV/3 "Constitution, purpose and facilities of Salomon's House". Here we encounter the ideal type of a collection compiling all imaginable appearances.

However, there was no professional group who would be occupied directly with remembrance and retention of memory. These professionals emerged only later from the reality of the 18th and 19th centuries, in connection with the ongoing specialisation of museum collections and the institutionalisation of museums. Now let us skip this phase and take a final look at the present situation with "memory retention providers" (after G. Korff).

\section{From musealisation to present- day activist museum}

In the general discourse on memory culture, the museum as an institution plays an important role as a mediator and bearer. Museums are places where the memory of a group, a religion or a nation has been retained. Historiography and museums are co-forming the memory of a society. "The transformation of living past and tradition into history is also accomplished through the medium of musealisation." ${ }^{54}$ Is musealisation perhaps a new term for a sort of conservation and thereby also a compensation of what is threatened to be lost by an altered attitude to history? In the late 19th century, the principle of keeping dead things alive in an artistic way - even outside the museum sphere - was extended to objects whose nature does not allow to place them in a museum

\footnotetext{
54 SIEDER, Reinhard. Editorial. Orte der Erinnerung. Österreichische Zeitschrift für Geschichtswissenschaften, 1991, vol. 2, no. 4, p. 5.
}

building, as Eva Sturm once said. The musealisation process expands into further spheres of life; in compensation for a loss of intimacy even manufacturing plants, industrial areas and landscapes are musealised. ${ }^{55}$

In the early "museological" texts, the memoria leads both to ordering principles and to objects. As far as the remembrance and forgetting in difficult historical reconciliation processes are concerned, it comes to light how many "problematic" (in the sense of "burdened") ideologyresistant objects persist - mostly unconsciously - in a museum. Not only the remembrance, but above all the forgetting, the phenomenon of suppression, forgetting through self-censorship, are holding the central place in historical research. Remembrance reconstitutes itself within a reference framework; if this context is missing, things are forgotten. Baberowski and Singer regard this not only as an epistemic problem concerning the reliability of sources, but mainly as a phenomenon which per se writes and rewrites history. The fundamental problem which arises with associative memory is the overwriting of the old by the new. Associative memory has the desired special property of supplementing and re-combining individual pieces of partial information. The forgotten, "however, can be reactivated again - to the surprise of all participants - in an altered context through new associations. The memory is revived again, but now in a different narrative context." 56

Methodical approaches in historical research, as exemplified by

\footnotetext{
55 REISINGER, Nikolaus. Musealisierung als Theorem der Museologie. Zur Musealisierung von Großobjekten und Landschaften am Beispiel der Eisenbahn. Curiositas, 2012/13, no. 12/13, pp. 55-68.

56 SINGER, Wolf. Der Beobachter im Gehirn. Essays zur Hirnforschung. Frankfurt a. M.: Suhrkamp Verlag, 2009, p. 84.
} 
oral history, and new types of museums acting as a reference framework and a space for social communication, might help to eliminate the "difference"57 between experiencing and interpreting the Present and experiencing and explaining the Past.

The localisation in space becomes irrelevant with intensified virtualisation. Individual objects of a collection or a museum can be interactively selected and randomly interrelated, associated with one another and - as it is partly the case with participative museums even interpreted. In this way everybody can create their own order, build a theatrum mundi of their own world and give it a new meaning.

Today, museums are established to account for incisive historical events, such as, for example, the Holocaust Memorial Museum in Washington. The contemporary approach of the so-called "activist museums", which are currently treated by J. Schellnbacher in her dissertation, represents indeed a different type of keeping memory: "Memories are not only preserved in museums, they are also made!"58 The knowledge, the experiences as well as the concerns and the associated objects, which are brought by the visitors, shall be incorporated in the exhibition structure. "Learn - remember confront." 59 The space provided is used not only for presentation of objects (fifty percent), but also for communication and research. The

57 After BABEROWSKI, Jörg. Der Sinn der Geschichte. Geschichtstheorien von Hegel bis Foucault. 3rd ed. München: C. H. Beck, 2014, Chapter 8: Erinnerung und Kollektives Gedächtnis, p. 162.

58 MCLAUGHLIN, Hooley. The Pursuit of Memory: Museums and the Denial of Fulfilling Sensory Experience. Journal of Museums Education, 1998, vol. 23, no. 3, p. 10.

59 United States Holocaust Memorial Museum [online]. [cit. 2017-11-23]. Available from www: <https://www.ushmm.org/>. goals of this new type of museums are ambitious and progressive: inclusion, integration and tolerance.

\section{BIBLIOGRAPHY:}

AIGNER, Heribert. Museale Vorläufer vom Alten Orient bis in die griechischrömische Welt. Curiositas, 2001, no. 1, pp. 81-87. ISSN 0237-8388.

ARENDT, Hannah. Vita activa oder Vom tätigen Leben. München, 1981.

ASSMANN, Aleida. Erinnerungsräume. Formen und Wandlungen des kulturellen Gedächtnisses. München: C. H. Beck, 1999. ISBN 978-3-406-44670-2.

ASSMANN, Jan. Kollektives Gedächtnis und kulturelle Identität. In ASSMANN, Jan and Tonio HÖLSCHER (eds.). Kultur und Gedächtnis. Frankfurt a. M.: Suhrkamp, 1988, pp. 9-19. ISBN 3-518-28324-3.

BABEROWSKI, Jörg. Der Sinn der Geschichte. Geschichtstheorien von Hegel bis Foucault. 3rd ed. München: C. H. Beck, 2014. ISBN 978-3-406-66917-0.

BACH, Gerlinde. Philipp Hainhofer und ein Kabinettschrank des Kunsthistorischen Museums in Wien. Philipp Hainhofer Kunsthändler, Agent und Auftraggeber zahlreicher Kabinettschränke. In Jahrbuch der Kunsthistorischen Sammlungen in Wien, 1995/1996, vol. 91, pp. 111-151. ISBN 978-3-201-00398-8.

BESSLER, Gabriele. Wunderkammern einst und heute - die Welt im Raum. Konzeptuelle Ansätze für museale Kunstkammer-Inszenierungen. In ULFERTS, Gert-Dieter and Thomas FÖHL (eds.). Von Berlin nach Weimar. Von der Kunstkammer zum Neuen Museum. München, Berlin: Deutscher Kunstverlag, 2003, pp. 236-253. ISBN 978-3-42206431-7.

CSÁKY, Moritz and Peter STACHEL (eds.). Speicher des Gedächtnisses. Bibliotheken, Museen und Archive. Volume 1:

Absage an und Wiederherstellung von Vergangenheit. Kompensation von Geschichtsverlust. Wien: Passagen Verlag, 2000. ISBN 978-3-85165-454-7.

CSÁKY, Moritz and Peter STACHEL (eds.). Speicher des Gedächtnisses. Bibliotheken, Museen und Archive. Volume 2: Die Erfindung des Ursprungs.
Die Systematisierung der Zeit. Wien: Passagen Verlag, 2001. ISBN 978-3-85165-458-5.

DOERING, Oscar. Des Augsburger Patriciers Philipp Hainhofer Reisen nach Innsbruck und Dresden. Wien: C. Graeser, 1901.

DROYSEN, Johann Gustav. Grundriss Der Historik. 2nd ed. Leipzig: Veit \& Comp., 1875.

ELSNER, John and Roger CARDINAL (eds.). The Cultures of Collecting. London: Reaktion Books, 1996, p. 1. ISBN 0-948462-51-5.

ERNST, Ulrich. Memoria und ars memorativa in der Tradition der Enzyklopädie. Von Plinius zur Encyclopédie française. In BERNS, Jörg Jochen and Wolfgang NEUBER (eds.). Seelenmaschinen. Gattungstraditionen, Funktionen und Leistungsgrenzen der Mnemotechniken vom späten Mittelalter bis zum Beginn der Moderne. Wien, Köln, Weimar: Böhlau, 2000, pp. 109-168. ISBN 978-3-205-99148-9.

FOER, Joshua. Moonwalking with Einstein: the art and science of remembering everything. London: Penguin Books, 2012. ISBN 978-0-14-103213-9.

FOUCAULT, Michel. Die Ordnung der Dinge. 2nd ed. Frankfurt a. M.: Suhrkamp Taschenbuch Wissenschaft, 1978. ISBN 978-3-518-07696-5.

FUENTES, Carlos. Terra Nostra. Barcelona: Martin Secker \& Warburg Ltd, 1977. ISBN 0-436-16760-3.

GALTER, Hannes D. Geschichte als Bauwerk. Der Aššurtempel und das assyrische Geschichtsbewusstsein. In FRAME, G. (ed.). From the Upper to the Lower Sea. Festschrift für A. K. Grayson. Leiden, 2004. [non-paginated manuscript of the author].

KELLER, Barbara. Mnemonik als kreatives Verfahren im 16. und 17. Jahrhundert. In ASSMANN, Aleida and Dietrich HARTH (eds.). Mnemosyne. Formen und Funktion kultureller Erinnerung. Frankfurt a. M.: Fischer-Taschenbuch-Verlag, 1991, pp. 200-216. ISBN 978-3-596-10724-7.

KLEINSPEHN, Thomas. Der flüchtige Blick. Sehen und Identität in der Kultur der Neuzeit. Reinbek bei Hamburg: RowohltTaschenbuch, 1991. ISBN 978-3-499-55485-8. 
KNELL, Simon J. (ed.). Museums and the Future of Collecting. Aldershot: Ashgate, 2004. ISBN 0-7546-3005-6.

KORFF, Gottfried. Das historische Museum. Labor, Schaubühne, Identitätsfabrik. Frankfurt a. M.: Campus-Verlag, 1990. ISBN 3-593-34349-5.

MCLAUGHLIN, Hooley. The Pursuit of Memory: Museums and the Denial of Fulfilling Sensory Experience. Journal of Museums Education, 1998, vol. 23, no. 3, pp. 10-12. ISSN 1059-8650. DOI: https:// doi.org/10.1080/10598650.1998.11510385

NEUMEISTER, Sebastian. Der Schriftsteller und die Erinnerung: Carlos Fuentes und das "Teatro della memoria" des Giulio Camillo Delminio. Ibero-amerikanisches Archiv, 1990, vol. 16, no. 1, pp. 31-47. ISSN 0340-3068.

OLMI, Guiseppe. Dal "Teatro del mondo" ai mondi inventariati: aspetti e forme del collezionismo nell' età moderna. In OLMI, Guiseppe. L'inventario del mondo. Catalogazione della natura e luoghi del sapere nella prima età moderna. Bologna: Il Mulino, 1992, pp. 165-209. ISBN 978-88-15-03647-6.

RAFFLER, Marlies. Museum - Spiegel der Nation. Zugänge zur Historischen Museologie am Beispiel der Genese von Landes- und Nationalmuseen in der Habsburgermonarchie. Wien, Köln, Weimar: Böhlau, 2008. ISBN 978-3-205-77731-1.

RAFFLER, Marlies. Sammeln, die ordnende Weltsicht. Aspekte zur Historischen Museologie. Curiositas, 2001, no. 1, pp. 67-80. ISSN 0237-8388.

REISINGER, Nikolaus. Musealisierung als Theorem der Museologie. Zur Musealisierung von Großobjekten und Landschaften am Beispiel der Eisenbahn. Curiositas, 2012/13, no. 12/13, pp. 5568. ISSN 0237-8388.

ROTH, Harriet (ed.). Der Anfang der Museumslehre in Deutschland: das Traktat „Inscriptiones vel tituli theatri amplissimi“ von Samuel Quiccheberg; lateinischdeutsch. Berlin: De Gruyter, 2000. ISBN 978-3-05-003490-4.

SIEDER, Reinhard. Editorial. Orte der Erinnerung. Österreichische Zeitschrift für Geschichtswissenschaften, 1991, vol. 2, no. 4 , p. 5 .

SINGER, Wolf. Der Beobachter im Gehirn. Essays zur Hirnforschung. Frankfurt a.
M.: Suhrkamp Verlag, 2009. ISBN 978-3-518-29171-9.

SINGER, Wolf. Wahrnehmen, Erinnern,

Vergessen. Über Nutzen und

Vorteil der Hirnforschung für die Geschichtswissenschaft. Eröffnungsvortrag des 43. Deutschen Historikertages am 26.09.2000 in Aachen [online]. [cit. 2017-11-22]. Available from www: $<$ http://www.brain.mpg.de/fileadmin/ user_upload/images/Research/Emeriti/ Singer/Historikertag.pdf $>$.

SÜNDERHAUF, Esther. Im Labyrinth des Visus. Wahrnehmungsformen in der Kunstkammer am Beispiel von Studiolo und Tribuna des Francesco I. de Medici. Frühneuzeit-Info, 1996, vol. 7, no. 2, pp. 215-233. ISSN 0940-4007.

THIEMEYER, Thomas.

Geschichtswissenschaft. Das Museum als Quelle. In BAUR, Joachim (ed.). Museumsanalyse. Methoden und Konturen eines neuen Forschungsfeldes. 2nd ed. Bielefeld: Transcript, 2013, pp. 73-94. ISBN 978-3-89942-814-8.

United States Holocaust Memorial Museum [online]. [cit. 2017-11-23]. Available from www: <https://www.ushmm.org/>.

WAIDACHER, Friedrich. Handbuch der Allgemeinen Museologie. 2nd ed. Wien, Köln, Weimar: Böhlau, 1999. ISBN 3-205-99130-3.

WAIDACHER, Friedrich. Museologie - knapp gefasst. Mit einem Beitrag von Marlies Raffler. Wien: UTB, 2005. ISBN 978-3-8252-2607-7.

WEINRICH, Harald. Gibt es eine Kunst des Vergessens? Basel: Schwabe, 1996. ISBN 978-3-7965-1026-7.

WOOLEY, C. Leonard. The Excavations at Ur, 1924-1925. The Antiquaries Journal, 1925, vol. 5, no. 4, pp. 347-402. ISSN 0003-5815.

YATES, Francis. Gedächtnis der Renaissance: das Gedächtnistheater des Giulio Camillo. In YATES, Francis. Gedächtnis und Erinnern. Mnemonik von Aristoteles bis Shakespeare. 5th ed. Berlin: Akademie, 1999, pp. 123-161. ISBN 3-05-006059-X. 